\title{
16. LARGE-SCALE ELECTRICAL RESISTIVITY AND BULK POROSITY OF THE UPPER OCEANIC CRUST AT HOLE 395A ${ }^{1}$
}

\author{
Keir Becker ${ }^{2}$
}

\begin{abstract}
A long-spaced, DC electrical resistivity experiment was run during Leg 109, through over $400 \mathrm{~m}$ of the upper oceanic crust in Hole 395A. The same experiment had been run during Leg 83 in Hole 504B, and the results from the two holes are compared. This experiment responds to in-situ crustal resistivities over vertical and radial averaging scales of about $5-50 \mathrm{~m}$, and is quite sensitive to the large-scale porosity of the crust. Apparent crustal resistivities are about $30 \mathrm{ohm}-\mathrm{m}$ through most of the pillow lavas cored in Hole 395A, and increase to about 300 ohm-m at the base of a thick unit of sealed pillows near the bottom of the hole. A cyclic downhole variation of resistivity with a wavelength of $20-100 \mathrm{~m}$ correlates with the main lithologic units; within each unit, resistivity increases and porosity decreases with depth. Bulk porosities in Hole 395A were estimated by applying Archie's Law, and range from $10 \%-15 \%$ in the uppermost pillows to about $4 \%$ in the resistive unit near the bottom of the hole. These porosity values are remarkably similar to the upper crustal porosities obtained in Hole 504B, although the porosity and sonic structure of the crust at Hole 395A are much less clearly defined than at Hole 504B.
\end{abstract}

\section{INTRODUCTION}

The circulation of seawater through basalts and sediments plays a key role in development of the physical and chemical nature of the upper oceanic crust. The modes and effects of this circulation are themselves partly controlled by the variable permeability and porosity of the basaltic layer. As the porosity and permeability of the upper oceanic crust probably depend on irregular fracturing and voids of uncertain scale, they cannot be reliably determined from dredged or cored samples. Instead, independent determinations of bulk porosity are essential in relating physical properties measured on recovered samples to the bulk formation properties of the crust. Given present technology, the bulk porosity and permeability of the crust are best measured in situ from deep boreholes, preferably at averaging scales large enough to escape the disturbance of drilling on the surrounding formation, as well as to fully include the effects of irregular fracture porosity.

We report here the results of such an in-situ experiment, a large-scale electrical resistivity log conducted during Leg 109 of the Ocean Drilling Program (ODP) in one of the deepest boreholes yet drilled into the oceanic crust, Hole 395A near the Mid-Atlantic Ridge. Over typical upper crustal temperatures $\left(5^{\circ}-20^{\circ} \mathrm{C}\right.$ in Hole $\left.395 \mathrm{~A}\right)$, the electrical conductivity of the pore fluid, essentially seawater, is several orders of magnitude greater than the intrinsic conductivity of the host basalt. Therefore, although this experiment does not directly measure porosity, the results are highly sensitive to the bulk porosity of the crust at Hole 395A.

The very same large-scale resistivity (LSR) experiment was previously run in the deepest hole into the oceanic crust, Hole 504B (Becker et al., 1982; Von Herzen et al., 1983; Becker, 1985), providing widely-cited reference profiles of the resistivity and bulk porosity of the upper oceanic crust. The comparison of results from Holes 395A and 504B is a primary focus of this paper, which therefore parallels Becker (1985) in

\footnotetext{
1 Detrick, R., Honnorez, J., Bryan, W. B., Juteau, T., et al., 1990. Proc. ODP, Sci. Results, 106/109: College Station, TX (Ocean Drilling Program).

2 Division of Marine Geology and Geophysics, Rosenstiel School of Marine and Atmospheric Science, University of Miami, Miami, FL 33149.
}

exposition and analysis. In related papers, Kopietz et al. (this volume) and Becker (this volume) discuss the hydrogeology at Site 395 , as determined from in-situ measurements of temperature and permeability; here we concentrate on the bulk resistivity and porosity of the section penetrated by Hole 395 A and implications for other formation properties.

Hole $395 \mathrm{~A}$ is located about $110 \mathrm{~km}$ west of the Mid-Atlantic Ridge at $22^{\circ} 45^{\prime} \mathrm{N}$ (Fig. 1), in a small sediment pond in 7.3-m.y.-old crust under $4484 \mathrm{~m}$ of seawater (Fig. 2). The hole was cored during DSDP Leg 45 to a depth of $664 \mathrm{~m}$ below seafloor (mbsf), through $93 \mathrm{~m}$ of sediment and $571 \mathrm{~m}$ of basement (Melson, Rabinowitz, et al., 1979). The basement penetration in Hole $395 \mathrm{~A}$ is the third deepest achieved by DSDP/ODP, behind the $1287.8 \mathrm{~m}$ in Hole 504B and the $583 \mathrm{~m}$ in Hole 332. During 1981, Leg 78B revisited Hole 395A for logging and downhole measurements (Hyndman, Salisbury, et al., 1984), and found that the deepest $55 \mathrm{~m}$ of the hole was blocked, presumably by cavings. During 1986, Leg 109 revisited the hole again for logging and downhole measurements (Detrick, Honnorez, Bryan, Juteau, et al., 1988), and found that an additional $3 \mathrm{~m}$ of the hole was blocked. Thus, Leg 109 logged $494 \mathrm{~m}$ of open hole between the bottom of casing at 112 mbsf (or $19 \mathrm{~m}$ into basement) and the top of the blockage at 606 mbsf. The section logged during Leg 109 comprises mostly pillow lavas, with some flow units and breccias, and a thin section of plutonic cobbles (Melson, Rabinowitz, et al., 1979).

As the sediment pond at Hole $395 \mathrm{~A}$ is of only limited lateral extent, it is not an effective seal against circulation of seawater into the crust that the hole penetrates beneath the sediments. The measurements of downhole temperatures and permeabilities indicate that the upper $300-400 \mathrm{~m}$ of basement in Hole $395 \mathrm{~A}$ is sufficiently open to support active circulation, whereas the deepest $100-200 \mathrm{~m}$ is relatively impermeable, with a mostly conductive geothermal regime (Becker et al., 1984; Hickman et al., 1984; Langseth et al., 1984; Becker, this volume; Kopietz et al., this volume). The geothermal state of the crust at Hole $395 \mathrm{~A}$ contrasts with that at Hole 504B, where the thicker sediment layer forms a nearly continuous seal against circulation of seawater into the crust, which except for the upper $100-200 \mathrm{~m}$ is mostly sealed and impermeable to such circulation. Despite this apparent difference, when both holes were drilled ocean bottom water began flowing down the 


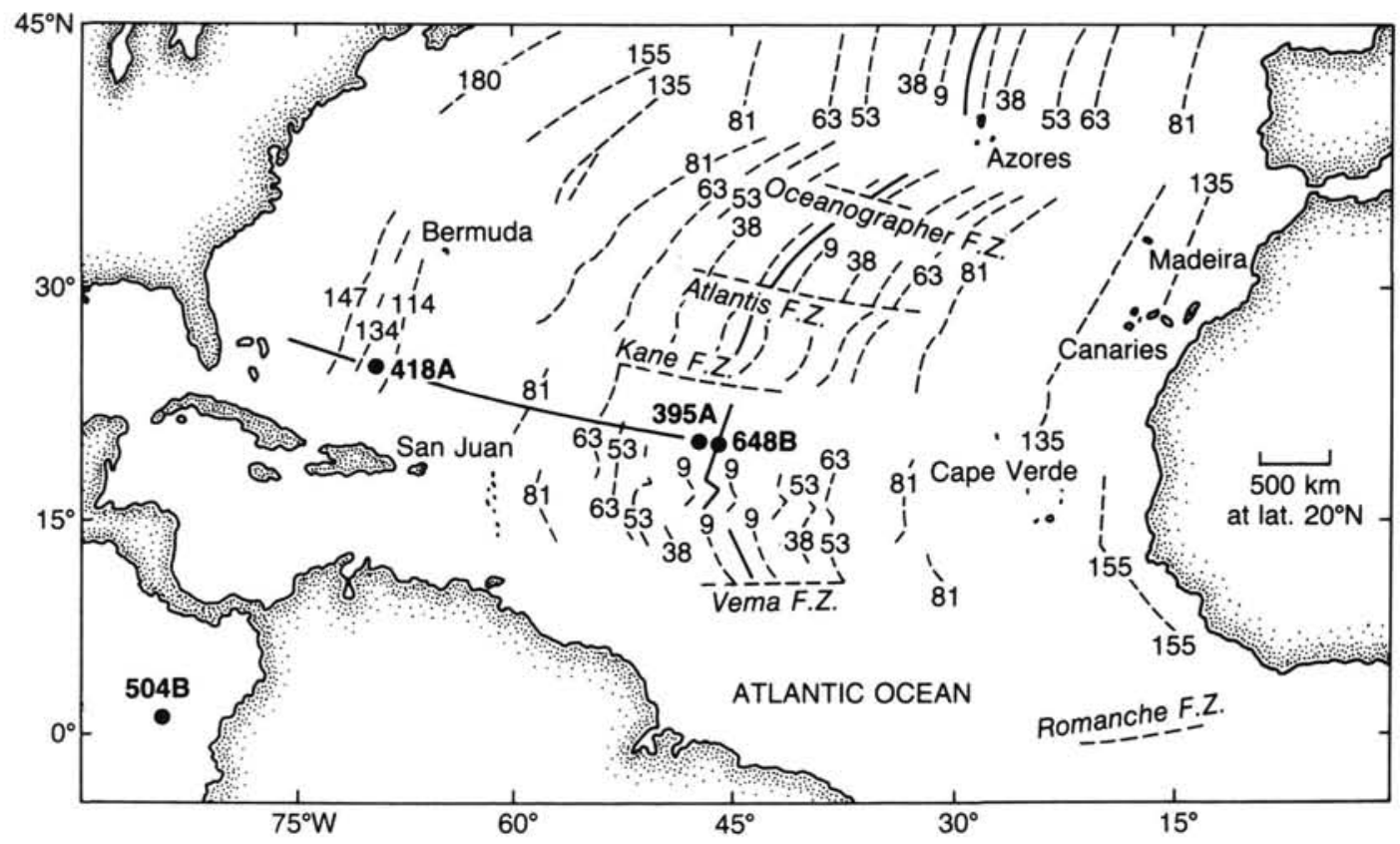

Figure 1. Locations of the two basement holes in which the large-scale resistivity experiment has been conducted, Hole 504B in the eastern equatorial Pacific and Hole 395A in the north Atlantic.

holes and into the upper permeable and porous sections of basement (Becker et al., 1983a, 1983b, 1984, 1985; Kopietz et al., this volume). This suggests that the hydrogeologic properties of the uppermost crust may be similar at the two holes, a suggestion which is apparently corroborated by comparison of the results of the large-scale resistivity experiments conducted in the two holes.

\section{EXPERIMENTAL PROCEDURE}

The large-scale resistivity experiment (LSR) was first deployed during Leg 60 by Francis (1982), who discussed the methods in detail. It was later run twice in Hole 504B, first during Leg 70 to a depth of 836 mbsf (Von Herzen et al., 1983), and again during Leg 83 to a depth of 1287.5 mbsf (Becker et al., 1982; Becker, 1985). The experiment (Fig. 3) is a simple, long-spaced, DC resistivity log, basically an adaptation of the earliest kind of resistivity logging (Schlumberger et al., 1934a, 1934b; Runge et al., 1969). A large current is passed from the ship down the armored logging cable, through an insulated cable to a steel sinker-bar that acts as a current electrode. The current then returns through the formation and sea back to the ship. Francis (1982) showed that, despite the conductive seawater in the hole, the long, narrow seawater return path up the borehole is relatively resistive, so that the current may be taken to return through the formation. He also showed that neither the casing nor the armored logging cable shunt the current return path. A potential gradient arises in the hole due to the resistivity of the formation, and is sampled with several nonpolarizing $\mathrm{Ag} / \mathrm{AgCl}$ electrodes spaced up the insulated cable.

Figure 3 shows the downhole electrode configuration that was deployed both in Hole 504B during Leg 83 and in Hole 395A during Leg 109. Identical equipment and procedures were used in these two experiments, as follows: Four potential electrodes were spaced 10, 20, 40 , and $80 \mathrm{~m}$ above the current source, and the hole was logged at discrete, stationary intervals of $10 \mathrm{~m}$. At each measurement depth, current was passed for about $10 \mathrm{~s}$ each under positive and reversed voltage, to allow removal by averaging of any biases between electrodes arising from possible ambient potential gradients in the hole. Four potential differences were separately recorded $(1-2,2-3,3-4$, and $1-4)$, and the other two were obtained arithmetically. Currents and potential differences were measured to an estimated $1 \%-3 \%$ accuracy; the partial redundancy of the recorded potential differences demonstrated the quality of the data, as the sum of the interval voltages duplicated the overall voltage to within $1 \%$ at every depth.
Many depths were repeat-logged, with measured currents and voltages always repeating within $1 \%$. The basic parameters measured were the potential differences arising from the application of a known power source; the resistivity of the formation was obtained from these data by the analysis described in the following section.

\section{APPARENT RESISTIVITY}

It is likely that the resistivity of the upper crust varies both with depth and laterally, and the measured voltage differences are therefore related to the resistivity structure in a complicated, nonlinear fashion. The response of each electrode pair is a function of both the resistivity of the surrounding crust and the spacings among the potential and current electrodes (Dakhnov, 1962; Roy and Dhar, 1971). In effect, each electrode pair averages the crustal resistivity over a unique vertical and radial scale. Although the scale of investigation of a DC resistivity log is difficult to quantify, the analysis of Roy and Dhar (1971) indicates that the LSR investigates far enough into the formation (on the order of 5-50 m, depending on the electrode pair) to escape the effects of the disturbed zone near the borehole, where temperature, pressure, and porosity may be unrepresentative of truly in-situ conditions. The large-scale apparent resistivities presented here are thus interpreted as radially and vertically averaged in-situ crustal resistivities, with the poorly determined averaging scales dependent on the true resistivity structure.

For a long-spaced resistivity log, a first approximation of in-situ resistivities can be obtained by ignoring the borehole and assuming that the electrodes are embedded in the formation (e.g., Francis, 1982; Becker et al., 1982). This is equivalent to an assumption that the electrode spacings are large enough relative to the hole diameter that no geometric borehole correction to the measurements is necessary, an assumption that is questionable with a conductive, seawater-filled borehole and the moderate electrode spacings used in Holes $395 \mathrm{~A}$ and 504B. In fact, Becker (1985) showed that this assumption is probably valid for LSR results only in relatively conductive sediments or the most porous, conductive pillow lavas, and that a more exact formulation is required to determine crustal resistivities from LSR data. 


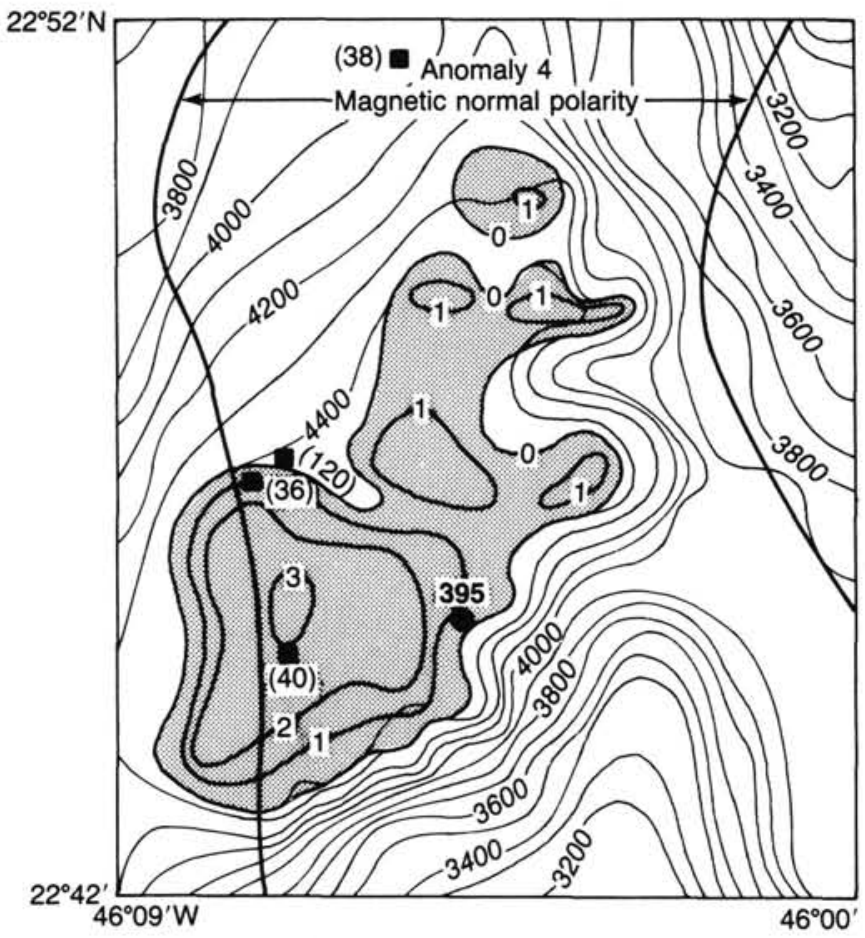

Figure 2. The sediment pond in which Hole 395A is located (after Hussong et al., 1979). Bathymetry is shown in corrected meters, and sediment isopachs are given in seconds of two-way traveltime. Also shown are the boundaries of magnetic anomaly 4 and heat flow values in $\mathrm{mW} / \mathrm{m}^{2}$.

For this study, a very close approximation to in-situ resistivities was obtained by applying the exact, analytic solution for the potential that arises from a point current source in a borehole that penetrates a locally homogeneous medium (e.g., Kunz and Moran, 1958; Gianzero and Rau, 1977). At the center of a seawater-filled borehole of radius $a$, the potential $V$ at a vertical distance $z$ from the current source $I$ is given by:

$$
V(z)=\frac{I p_{s w}}{4 \pi}\left\{\frac{1}{z}+\frac{2}{\pi a_{0}} \int^{\infty} d z A(x) \cos \frac{x z}{a}\right\}
$$

with

$$
A(x)=\frac{(1-\varepsilon) K_{0}(x) I_{0}(x)}{K_{0}(x) I_{1}(x)+\varepsilon K_{1}(x) I_{0}(x)}
$$

Here $\rho_{\mathrm{sw}}$ is the resistivity of the seawater in the borehole, is defined as the ratio of seawater resistivity to crustal resistivity $\rho_{\mathrm{a}}$, and $\mathrm{I}_{0}, \mathrm{I}_{1}, \mathrm{~K}_{0}$, and $\mathrm{K}_{1}$ are modified Bessel functions of the first and second kind.

Equation (1) cannot be analytically inverted to yield in-situ resistivities directly from the measured voltages. To obtain the apparent crustal resistivities reported here, the equation was integrated numerically for many values of $\epsilon$, to create arrays of calculated voltage differences appropriate to the various electrode pairs. Given the measured voltage differences, the actual values of $\epsilon$ were found by cubic spline interpolation within these arrays. The apparent resistivities were then obtained from the values of $\epsilon$ using a temperaturecorrected seawater resistivity:

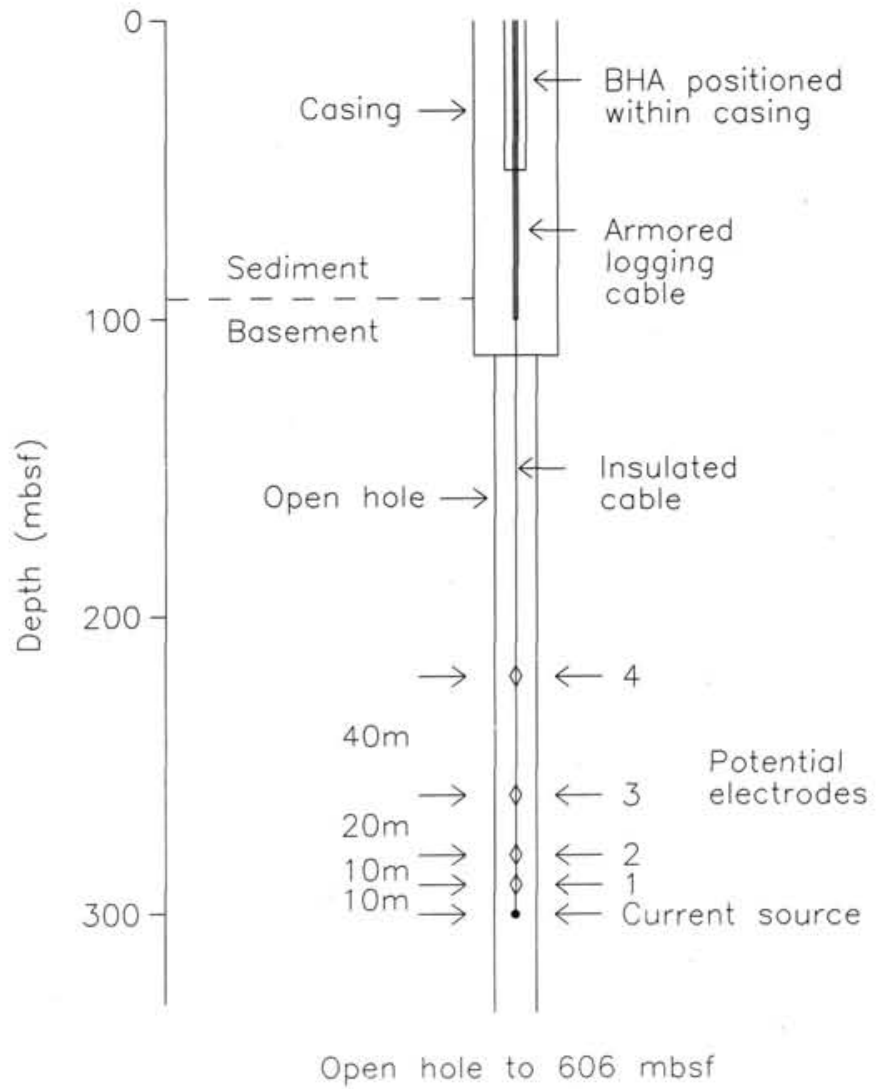

Figure 3. Schematic of the downhole electrode configuration used for the large-scale resistivity experiments in Holes 395A and 504B. BHA $=$ bottom-hole assembly.

$$
\rho_{s w}(\mathrm{ohm}-\mathrm{m})=\left[3+T\left({ }^{\circ} \mathrm{C}\right)\right]^{-1}
$$

(Fig. 4; Von Herzen et al., 1983; based on laboratory measurements of Horne and Frysinger, 1963; Quist and Marshall, 1968; and Bradshaw and Schleicher, 1980).

The only approximation involved in determining the apparent resistivities reported here is the assumption that the formation is uniformly resistive in the vicinity of the electrodes; therefore the apparent resistivities represent crustal resistivities averaged over vertical and radial scales that vary among the electrode pairs. As the measured potential gradient was more sensitive to resistivity variations where the current density was greater, or closer to the current source, the depths assigned to apparent resistivities were those of the deeper potential electrode,

Figure 5 shows apparent resistivities in Holes 395A calculated from voltages measured with the three electrode pairs with equidimensional spacings among the current electrode and potential electrodes (i.e., electrode pairs 1-2, 2-3, and $3-4$ on Fig. 3). These electrode pairs shared similar averaging characteristics, except that the longer-spaced pairs averaged farther into the formation, radially and vertically. Indeed, the profiles of apparent resistivities are increasingly smoothed with increasing electrode spacing. The greater detail in apparent resistivities from the shorter-spaced electrode pairs probably reflects better resolution of fine-scale variations in in-situ resistivities (as well as possible effects of hole washouts, particularly at $420 \mathrm{mbsf}$ ); the smoother apparent resistivities from the longer-spaced electrode pairs are probably more representative of the bulk properties of the crust.

The apparent resistivities in Figure 5 indicate that bulk crustal resistivities are on the order of $10-50 \mathrm{ohm}-\mathrm{m}$ in the 


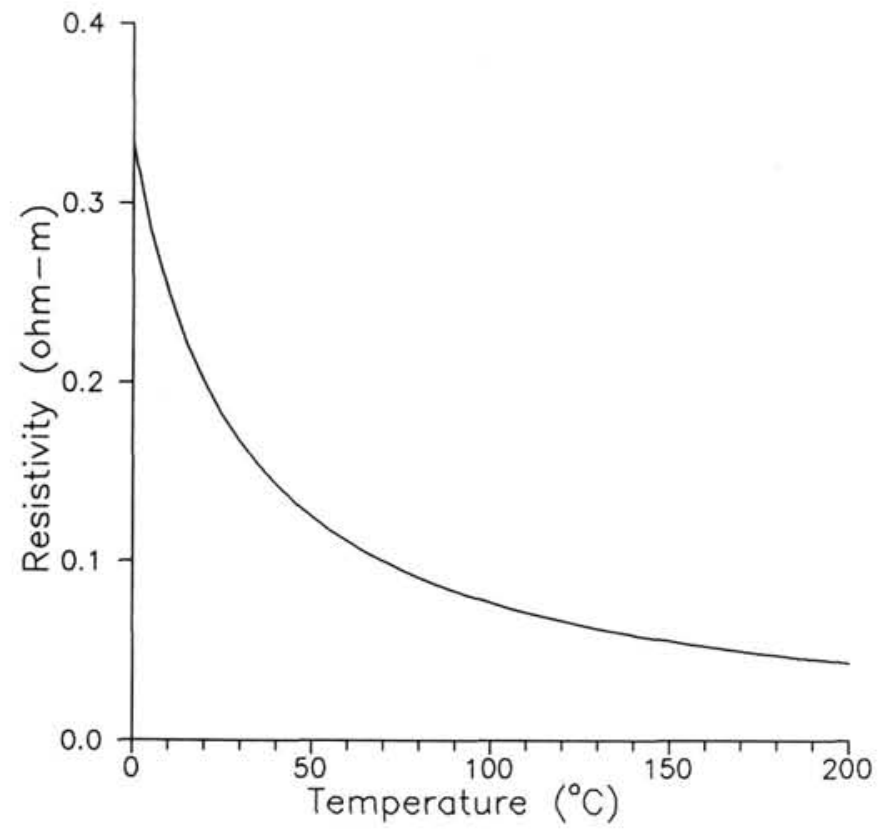

Figure 4. Linearized representation of the variation of the electrical resistivity of seawater (or upper crustal pore fluids) with temperature.

upper $300-400 \mathrm{~m}$ of pillow lavas, breccias, and minor flows cored in Hole 395A. Below this section, apparent resistivities increase in the deepest $100-150 \mathrm{~m}$ logged, reaching a peak value of about $300 \mathrm{ohm}-\mathrm{m}$ at about $580 \mathrm{mbsf}$. The resistivity profiles obtained with each of the three electrode pairs show cyclicities with typical downhole wavelengths of 20-100 m, which correlate quite well with the positions of the major aphyric and phyric units identified on Figure 5. Hyndman and Salisbury (1984) noted a similar pattern in the medium-spaced resistivity $\log$ conducted during Leg $78 \mathrm{~B}$, and attributed the increase of resistivity with depth in each of the lithologic units to a decrease in porosity within each unit. These results are generally confirmed by resistivities logged with a much shorter-spaced Schlumberger Spherically-Focused Laterolog during Leg 109 (Shipboard Scientific Party, 1988, Plate 1), except that the results from the latter are degraded in several zones with poor hole conditions (Moos, this volume).

The downhole variation of apparent resistivities in Hole $395 \mathrm{~A}$ is superficially similar to that in Hole 504B, where resistivities are fairly constant in the pillow lavas (but lower than in Hole 395A) and increase sharply across the transition into sheeted dikes at $600-700 \mathrm{~m}$ into basement (Fig. 6A). However, the increase in resistivities deep in Hole 395A occurs not at any clearly identified lithologic boundary, but within a large unit of aphyric basalts in which abundant fractures have been sealed by alteration products (Fig. 5). Below this, the blocked section that could not be logged includes breccias and brecciated pillow lavas (that are probably less resistive) and dolerite intrusions (that are probably quite resistive). Thus it is unclear whether the sharp increase of resistivities observed near the bottom of Hole 395A represents a regionally significant geophysical horizon.

The difference in average apparent resistivities in the upper sections of basement in Holes 395A (about $30 \mathrm{ohm}-\mathrm{m}$ ) and 504B (about $10 \mathrm{ohm}-\mathrm{m}$ ) is not indicative of any fundamental difference in basement structure, but instead can be attributed mostly to the effect of the conductivities of the pore fluids, which differ because of the large difference in crustal temperatures in the two holes $\left(5^{\circ}-20^{\circ} \mathrm{C}\right.$ at the depths logged in Hole $395 \mathrm{~A}, 55^{\circ}-145^{\circ} \mathrm{C}$ at the depths logged in Hole 504B). This will become apparent in the next section, in which the dependence of the measured resistivities on the conductive pore fluids will be exploited to estimate crustal porosities.

\section{APPARENT BULK POROSITY FROM APPARENT RESISTIVITY}

Given that the upper oceanic crust is a porous medium, with a pore fluid that is more conductive by orders of magnitude than the host basalts, in-situ logs of crustal resistivities must be strongly affected by crustal porosities. In commercial well logging, the porosity $\phi$ is often obtained directly from the measured resistivity $\rho_{\mathrm{m}}$ and the resistivity of the pore fluids $\rho_{\mathrm{f}}$ by applying the empirical Archie's (1942) law:

$$
F \equiv \frac{\rho_{m}}{\rho_{f}}=a \phi^{-m}
$$

where $F$ is the "formation factor," $a \approx 1$, and $m \approx 2$. Sundberg (1932) and Archie (1942) originally set $a=1$, which satisfies the condition that $F=1$ when $\phi=100 \%$. Jackson et al. (1978) found that a wide variety of natural and artificial sands follow this relationship, with $a=1$ and the exponent $m$ varying between 1 and 2 depending on particle shape and the resultant "tortuosity" of the porosity.

Although Archie's Law was empirically developed for sedimentary rocks of relatively uniform porosity, it has been applied with reasonable success to samples of both oceanic and continental basement (e.g., Brace et al., 1965; Brace and Orange, 1968; Hyndman and Drury, 1976; Karato, 1983). It has also been applied with reasonable consistency to in-situ logs of resistivity of the oceanic crust (e.g., Kirkpatrick, 1979; Salisbury et al., 1980; Becker et al., 1982; Cann and Von Herzen, 1983; Becker, 1985).

However, the application of Archie's Law to in-situ logs of crustal resistivity has not been rigorously justified, probably because of the threefold nature of the porosity of the oceanic crust: electrical conduction may occur via pore, crack, or fracture porosity (Brace, 1971). Nevertheless, empirical studies (e.g., Jackson et al., 1978) and theoretical models (e.g., Sen et al., 1981, and references therein) indicate that Archie's Law can be derived for the resistivity of water-saturated, non-clayey rocks, and it may therefore apply to much of the upper oceanic crust. If so, the form of the resistivity-porosity relationship probably depends on the nature of the porosity, which may vary within the crust. For example, exponents near or possibly greater than 2 have applied to measurements on basalt samples with dominantly grain-boundary porosity (Brace et al., 1965; Brace and Orange, 1968; Karato, 1983), whereas exponents near or possibly less than 2 have applied in interpreting logging measurements in the fractured upper levels of oceanic basement (e.g., Kirkpatrick, 1979; Salisbury et al., 1980; Cann and Von Herzen, 1983).

In addition, electrical conduction in the crust may be enhanced by the presence of conductive alteration products, particularly certain zeolites (e.g., Waxman and Smits, 1968; Worthington, 1975; Olhoeft, 1981). Where such alteration products are present, they may result in lower measured resistivities and over-estimated porosities, unless a correction term for surface conduction is included in Archie's Law (Waxman and Smits, 1968; Hill et al., 1979). For example, Pezard et al. (in press) and Pezard and Anderson (in press) found that surface conduction due to alteration affects measured resistivities and estimated porosities in certain sections of Hole 504B.

In treating log data, the Archie's Law exponent has usually been estimated by referring measured resistivities against porosities determined from other logs, particularly neutron 


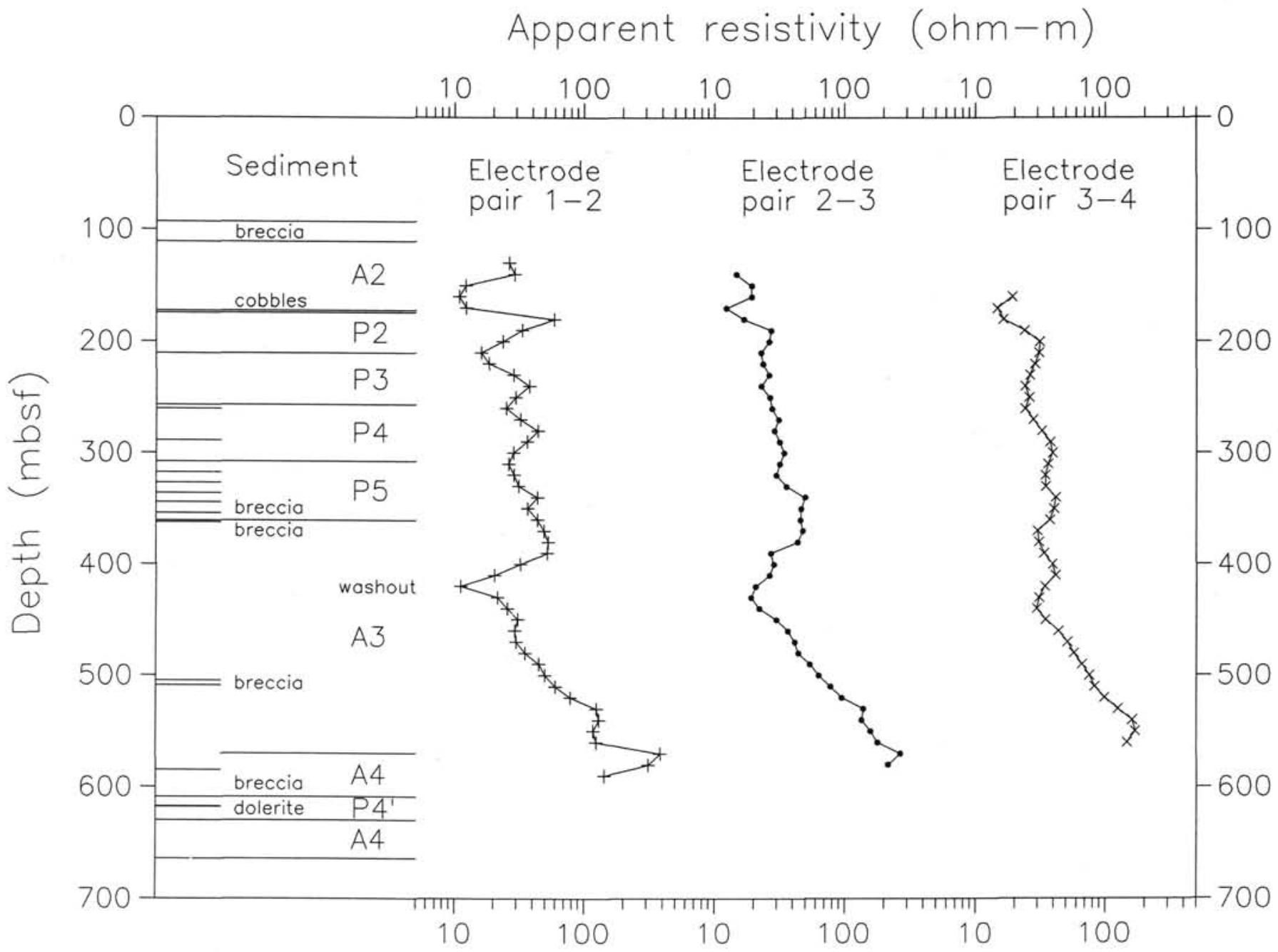

Figure 5. Lithology in Hole 395A and apparent resistivities determined from voltages measured with electrode pairs 1-2, 2-3, and 3-4. Lithology summarized from Shipboard Scientific Party (1979), who identify 23 lithologic units (delimited by short horizontal lines on left), most of which belong to 9 major chemical/magnetic types (delimited with long horizontal lines on left). These chemical/magnetic types are composed mostly of aphyric (A2-A4) or phyric (P2-P5 and P4') pillow lavas, with some minor flows, and are sometimes separated by breccias or cobbles. Note the correlation of these nine types with the variations in apparent resistivities, particularly those measured with the shortest-spaced electrode pair, $1-2$.

and density logs. However, the algorithms for determining porosities from these logs are also not rigorously justified for the oceanic crust, and it is not clear which of the logs (resistivity, density, neutron, or even sonic logs) yields the most realistic estimates of porosity. The log-determined porosities cannot be properly calibrated, primarily because the large-scale fracture porosity cannot be adequately represented in the recovered cores. For example, the neutron logs from Hole 504B yielded significantly higher estimates of porosities than the resistivity logs (see Anderson et al., 1985; Newmark et al., 1985a, 1985b; Becker, 1985; Salisbury et al., 1985; Broglia and Ellis, 1988). Unfortunately, all of the standard logs from Hole $395 \mathrm{~A}$ are degraded to some degree by poor hole conditions (Moos, this volume), and it is very difficult to calibrate the porosities derived from the logs (Broglia and Ellis, 1988) or the possible effects of alteration products on porosities estimated from resistivities.

Without further justification, we used Archie's Law to obtain a first approximation to bulk crustal porosities in the section penetrated by Hole $395 \mathrm{~A}$, just as Becker (1985) estimated porosities in Hole 504B, compromising on an average exponent $m=2$. The salinity of the pore fluids in both holes corresponds closely to that of seawater (Mottl et al., 1983; McDuff, 1984), so the temperature-sensitive resistivity of seawater was used for that of the pore fluids. The resistivity of seawater varies by factors of two over the ranges of crustal temperatures in both Holes $395 \mathrm{~A}\left(5^{\circ}-20^{\circ} \mathrm{C}\right)$ and $504 \mathrm{~B}$ $\left(55^{\circ}-150^{\circ} \mathrm{C}\right.$ ) (Fig. 4), and is two to three times greater at comparable depths in Hole 395A than in Hole 504B.

Figure 6B shows apparent bulk porosities in Holes 395A and $504 \mathrm{~B}$, calculated using resistivities determined from the longest-spaced electrode pair, 3-4, which yielded the largestscale averages of in-situ resistivities. As alluded to earlier, although upper crustal resistivities are roughly three times greater in Hole $395 \mathrm{~A}$, the estimated upper crustal porosities are nearly identical in the two holes, simply because the pore fluid resistivity is also nearly three times greater in the cooler Hole 395A. Apparent bulk porosities are on the order of $10 \%-15 \%$ in the upper sections of both holes, and noticeably decrease with depth in both holes. As noted in discussing the resistivities, the sharp decrease in porosities at $900 \mathrm{mbsf}$ in Hole 504B corresponds to a major lithologic transition. However, the decrease in apparent bulk porosities at $350-450 \mathrm{mbsf}$ in Hole 395A occurs primarily within a single lithologic unit 


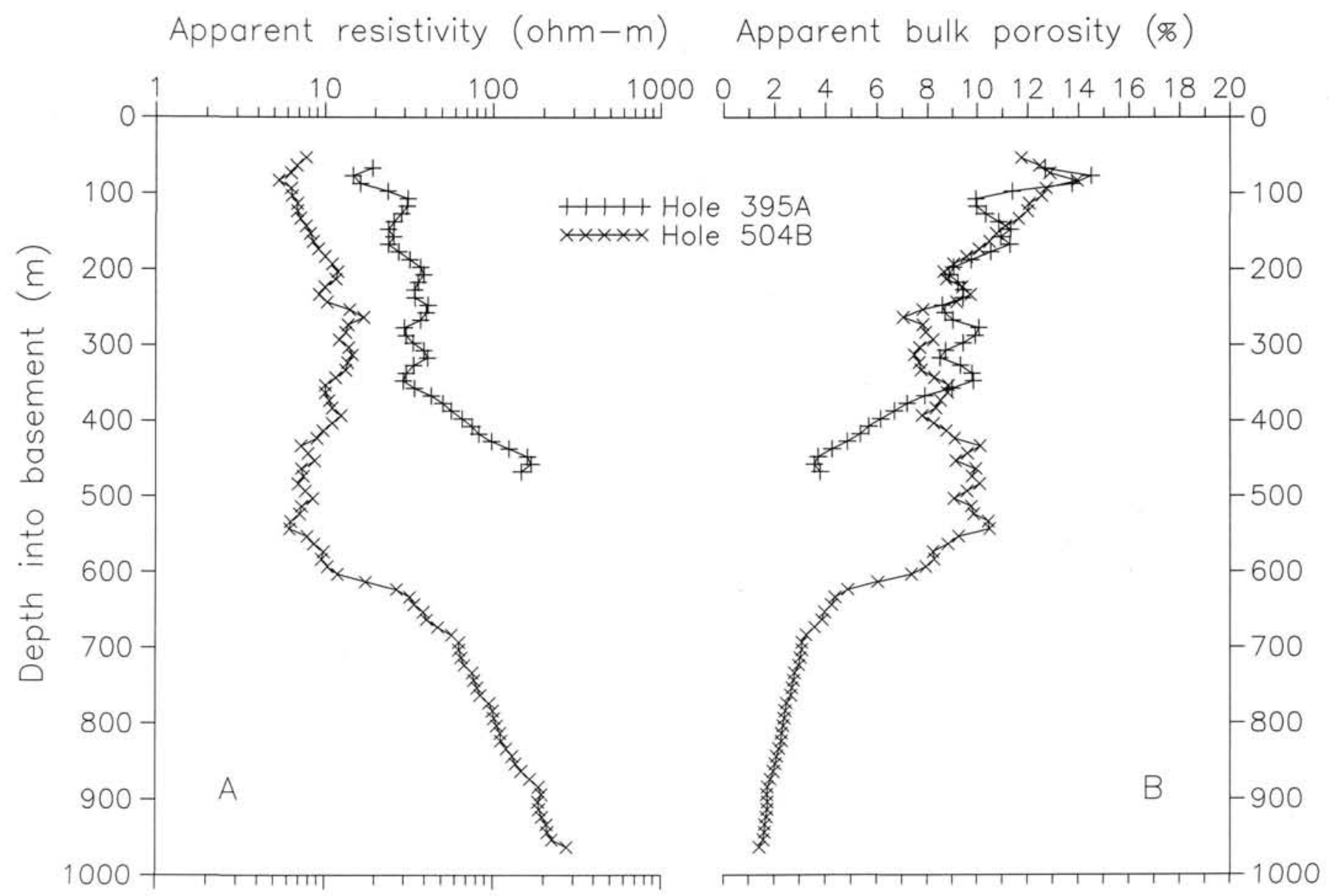

Figure 6. A. Apparent resistivities vs. depth into basement in Holes 395A and 504B, as determined with the longest-spaced electrode pair, 3-4. B. Apparent bulk porosities vs. depth into basement in Holes 395A and 504B, determined by applying Archie's (1942) Law to the apparent resistivities measured shown in Figure $6 \mathbf{A}$.

which is more completely sealed with depth, and it is not clear whether porosities below this unit remain low.

\section{DISCUSSION: BULK POROSITY AND SEISMIC STRUCTURE}

In Hole 504B, the apparent bulk porosities fall neatly into three layers that correlate closely with sonic Layers $2 \mathrm{~A}, 2 \mathrm{~B}$, and 2C (Becker et al., 1982; Anderson et al., 1982; Becker, 1985; Newmark et al., 1985a, 1985b, Salisbury et al., 1985), and the overall gradient in porosity is consistent with the gradient in Layer 2 seismic velocities (Stephen and Harding, 1983; Little and Stephen, 1985). In addition, upper crustal velocities are laterally quite variable, possibly related to local variability in the sealing of porosity as the crust ages (Stephen, 1985, 1988).

In contrast, although apparent bulk porosities are similar in Hole 395A, they do not fall into obvious layers, nor do the logged sonic velocities indicate a clear division of the section into subdivisions of Layer 2 . Instead, porosities generally decrease cyclically about a gradient with depth in Hole 395A, that is similar to the overall gradient in porosities in Hole 504B. The cyclicities correlate with the major lithologic units in Hole 395A, with porosities decreasing and sonic velocities increasing with depth within each of these units (Moos, this volume).

In a near-bottom seismic refraction experiment designed to be sensitive to upper crustal structure, Purdy (1987) found that the seismic structure of the upper crust in the vicinity of Site 395 is surprisingly uniform laterally and is characterized by a nearly constant velocity typical of Layer $2 \mathrm{~B}$. Thus it would appear that the cyclicities in resistivities, porosities, and sonic velocities logged downhole are averaged out in the seismic data. However, as Purdy's (1987) results apparently apply to the upper $250 \mathrm{~m}$ of basement, it is not clear whether the sharp resistivity increase and porosity decrease deep in Hole $395 \mathrm{~A}$ is significant in the regional seismic structure.

Purdy (1987) also shows that much lower upper crustal velocities characterize the crust now at the axis of the Mid-Atlantic Ridge where the crust at Site 395 was formed 7.3 m.y. ago. He therefore infers that the upper crustal velocities at Site 395 have been strongly modified since the crust was originally formed, by some combination of mechanisms that produced a strong reduction in upper crustal porosities as the crust aged. The results of the large-scale resistivity experiment presented here show no obvious evidence for such a process, but this experiment really cannot resolve temporal changes in the upper crustal resistivity and porosity at Hole $395 \mathrm{~A}$. However, future developments in the analyses of downhole logs and experiments, particularly neutron activation "geochemical" logs (e.g., Anderson et al., 1985, in press), may eventually begin to unravel the history of alteration at Site 395 and its effect on porosity and seismic velocities.

\section{ACKNOWLEDGMENTS}

The assistance of T. Gustafson and R. Current was invaluable in conducting the large-scale resistivity experiments in both Holes 395A 
and $504 \mathrm{~B}$, and is gratefully acknowledged. This study was supported by NSF grants OCE 81-17693, OCE 85-13537, and OCE 88-00077.

\section{REFERENCES}

Anderson, R. N., Honnorez, J., et al., 1982. DSDP Hole 504B, the first reference section over $1 \mathrm{~km}$ through Layer 2 of the oceanic crust. Nature, 300:589-594.

Anderson, R. N., O'Malley, H., and Newmark, R. L., 1985. Use of geophysical logs for quantitative determination of fracturing, alteration, and lithostratigraphy in the upper oceanic crust, Deep Sea Drilling Project, Holes 504B and 556. In Anderson, R. N., Honnorez, J., Becker, K., et al., Init. Repts. DSDP, 83: Washington (U.S. Govt. Printing Office), 443-478.

Anderson, R. N., Alt, J. C., and Malpas, J., in press. Integrated chemical fluxes from geochemical logs in Hole 504B, eastern equatorial Pacific. In Becker, K., Sakai, H., et al., Proc. ODP, Sci. Results, 111: College Station, TX (Ocean Drilling Program).

Archie, G. E., 1942. The electrical resistivity $\log$ as an aid in determining some reservoir characteristics, Petroleum Trans. AIME, 146:54-62.

Becker, K., 1985. Large-scale electrical resistivity and bulk porosity of the oceanic crust, Deep Sea Drilling Project Hole 504B, Costa Rica Rift. In Anderson, R. N., Honnorez, J., Becker, K., et al., Init. Repts. DSDP, 83: Washington (U.S. Govt. Printing Office), 419-427.

Becker, K., Von Herzen, R. P., Francis, T.J.G., et al., 1982. In situ electrical resistivity and bulk porosity of the oceanic crust, Costa Rica Rift, Nature, 300:594-598.

Becker, K., Langseth, M. G., and Von Herzen, R. P., 1983a. Deep crustal geothermal measurments, Hole 504B, Deep Sea Drilling Project Legs 69 and 70. In Cann, J. R., Langseth, M. G., Honnorez, J., Von Herzen, R. P., White, S. M., et al., Init. Repts. DSDP, 69: Washington (U.S. Govt. Printing Office), 223-236.

Becker, K., Langseth, M. G., Von Herzen, R. P., and Anderson, R. N., 1983b. Deep crustal geothermal measurements, Hole 504B, Costa Rica Rift. J. Geophys. Res., 88:3447-3457.

Becker, K., Langseth, M. G., and Hyndman, R. D., 1984. Temperature measurements in Hole 395A, Leg 78B. In Hyndman, R. D., Salisbury, M. H., et al., Init. Repts. DSDP, 78B: Washington (U.S. Govt. Printing Office), 689-698.

Becker, K., Langseth, M. G., Von Herzen, R. P., Anderson, R. N., and Hobart, M. A., 1985. Deep crustal geothermal measurements, Hole 504B, Deep Sea Drilling Project Legs 69, 70, 83, and 92. In Anderson, R. N., Honnorez, J., Becker, K., et al., Init. Repts DSDP, 83: Washington (U.S. Govt. Printing Office), 405-418.

Brace, W. F., 1971. Resistivity of saturated crustal rocks to $40 \mathrm{~km}$ based on laboratory studies. In Heacock, J.G. (Ed.), The Structure and Physical Properties of the Earth's Crust: Washington (Am. Geophys. Union), 243-255.

Brace, W. F. and Orange, A. S., 1968. Further studies of the effects of pressure on electrical resistivity of rocks. J. Geophys. Res., 73:5407-5420.

Brace, W. F., Orange, A. S., and Madden T. R., 1965. The effect of pressure on the electrical resistivity of water-saturated crystalline rocks. J.Geophys. Res., 70:5669-5678.

Bradshaw, A. L., and Schleicher, K. E., 1980. Electrical conductivity of seawater, IEEE J. Ocean Eng., OE5:50-62.

Broglia, C., and Ellis, D., 1988. Response of thermal neutron porosity $\log$ to alteration and environmental factors in basaltic rocks from ODP sites. EOS, Trans. AGU, 69:1403.

Cann, J. R., and Von Herzen, R. P., 1983. Downhole logging at Deep Sea Drilling Project Sites 501, 504, and 505, near the Costa Rica Rift. In Cann, J. R., Langseth, M. G., Honnorez, J., Von Herzen, R. P., White, S. M., et al., Init. Repts. DSDP, 69: Washington (U.S. Govt. Printing Office), 281-299.

Dakhnov, V. H., 1962. Geophysical well logging. Q. Colorado Sch. Mines, 57:1-443.

Detrick, W., Honnorez, J., Bryan, W. B., Juteau, T., et al., 1988. Proc. ODP, Init. Repts., 109: College Station, TX (Ocean Drilling Program).

Francis, T.J.G., 1982. Large-scale resistivity experiment at Deep Sea Drilling Project Hole 459B. In Hussong, D. M., Uyeda, S., et al., Init. Repts. DSDP, 60: Washington (U.S. Govt. Printing Office), 841-852.
Gianzero, S. C., and Rau, R., 1977. The effect of sonde position in the hole on the responses of resistivity tools. Geophysics, 42:642-654.

Hickman, S. H., Langseth, M. G., and Svitek, J. F., 1984a. In situ permeability and pore-pressure measurements near the mid-Atlantic Ridge, Deep Sea Drilling Project Hole 395A. In Hyndman, R. D., Salisbury, M. H., et al., Init. Repts. DSDP, 78B: Washington (U.S. Govt. Printing Office), 699-708.

Hill, H. J., Shirley, O. J., and Klein, G. E., 1979. Bound water in shaly sands-its relation to $\mathrm{Qv}$ and other formation properties. The Log Analyst, 20:3-19.

Horne, R. A. and Frysinger, G. R., 1963. The effect of pressure on the electrical conductivity of seawater. J. Geophys. Res., 68:1967-1973.

Hussong, D. M., Fryer, P. B., Tuthill, J. D., and Wipperman, L. K. 1979. The geological and geophysical setting near DSDP Site 395 , north Atlantic Ocean. In Melson, W. G., Rabinowitz, P. D., et al., Init. Repts. DSDP, 45: Washington (U.S. Govt. Printing Office), 23-37.

Hyndman, R. D. and Drury, M. J., 1976. The physical properties of oceanic basement rocks from deep drilling on the Mid-Atlantic Ridge, J. Geophys. Res., 81:4042-4052.

Hyndman, R. D. and Salisbury, M. H., 1984. The physical nature of young upper oceanic crust on the Mid-Atlantic Ridge, Deep Sea Drilling Project Hole 395A. In Hyndman, R. D., Salisbury, M. H., et al., Init. Repts. DSDP, 78B: Washington (U.S. Govt. Printing Office), 839-848.

Hyndman, R. D., Salisbury, M. H., et al., 1984. Init. Repts. DSDP, 78B: Washington (U.S. Govt. Printing Office).

Jackson, P. D., Taylor-Smith, D., and Stanford, P. N., 1978. Resistivity-porosity-particle shape relationships for marine sands. Geophysics, 43:1250-1268.

Karato, S., 1983. Physical properties of basalts from Deep Sea Drilling Project Hole 504B, Costa Rica Rift. In Cann, J. R., Langseth, M. G., Honnorez, J., Von Herzen, R. P., White, S. M. et al., Init. Repts. DSDP, 69: Washington (U.S. Govt. Printing Office), 687-695.

Kirkpatrick, R. J., 1979. The physical state of the oceanic crust: results of downhole geophysical logging in the Mid-Atlantic Ridge at $23^{\circ}$ N. J. Geophys. Res., 84:178-188.

Kunz, K. S. and Moran, J. H., 1958. Some effect of formation anisotropy on resistivity measurements in boreholes. Geophysics, 23:770-794.

Langseth, M. G., Hyndman, R. D., Becker, K., Hickman, S. H., and Salisbury, M. H., 1984. The hydrogeological regime of isolated sediment ponds in mid-oceanic ridges. In Hyndman, R. D., Salisbury, M. H., et al., Init. Repts. DSDP, 78B: Washington (U.S. Govt. Printing Office), 825-837.

Little, S. A. and Stephen, R. A., 1985. Costa Rica Rift borehole seismic experiment, Deep Sea Drilling Project Hole 504B, Leg 92. In Anderson, R. N., Honnorez, J., Becker, K., et al., Init. Repts. DSDP, 83: Washington (U.S. Govt. Printing Office), 517-528.

McDuff, R. E., 1984. The chemistry of interstitial waters from the upper ocean crust, Site 395, Deep Sea Drilling Project Leg 78B. In Hyndman, R. D., Salisbury, M. H., et al., Init. Repts. DSDP. 78B: Washington (U.S. Govt. Printing Office), 795-799.

Melson, W. G., Rabinowitz, P. D., et al., 1979. Init. Repts. DSDP, 45: Washington (U.S. Govt. Printing Office).

Mottl, M. J., Anderson, R. N., Jenkins, W. J., and Lawrence, J. R., 1983. Chemistry of waters sampled from basaltic basement in Deep Sea Drilling Project Holes 501, 504B, and 505B. In Cann, J. R., Langseth, M. G., Honnorez, J., Von Herzen, R. P., White, S. M., et al., Init. Repts. DSDP, 69: Washington (U.S. Govt. Printing Office), 475-483.

Newmark, R. L., Anderson, R. N., Moos, D., and Zoback, M. D. 1985a. Sonic and ultrasonic logging of Hole 504B and its implications for the structure, porosity, and stress regime of the upper 1 $\mathrm{km}$ of the oceanic crust. In Anderson, R. N., Honnorez, J., Becker, K., et al., Init. Repts. DSDP, 83: Washington (U.S. Govt. Printing Office), 479-510.

$1985 \mathrm{~b}$. Structure, porosity and stress regime of the upper oceanic crust: sonic and ultrasonic logging of DSDP Hole 504B. Tectonophysics, 118:1-42. 
Olhoeft, G. R., 1981. Electrical properties of rocks. In Touloukian, Y. S., Judd, W. R., and Roy, R. F. (Eds.), Physical Properties of Rocks and Minerals: New York (McGraw-Hill), 257-330.

Pezard, P. A., and Anderson, R. N., in press. Morphology and alteration of the upper oceanic crust from in-situ electrical experiments in Hole 504B. In Becker, K., Sakai, H., et al., Proc. ODP, Sci. Results, 111: College Station, TX (Ocean Drilling Program).

Pezard, P. A., Howard, J. J., and Lovell, M. A., in press. Clay conduction and pore structure of oceanic basalts from DSDP Hole 504B. In Becker, K., Sakai, H., et al., Proc. ODP, Sci. Results, 111: College Station, TX (Ocean Drilling Program).

Purdy, G. M., 1987. New observations of the shallow seismic structure of young oceanic crust. J. Geophys. Res., 92:9351-9362.

Quist, A. S. and Marshall, W. L., 1968. Electrical conductances of aqueous sodium chloride solutions from 0 to $800^{\circ} \mathrm{C}$ and at pressures to 4000 bars. J. Phys. Chem., 72:684-703.

Roy, A. and Dhar, R. L., 1971. Radius of investigation in DC resistivity well logging. Geophysics, 36:754-760.

Runge, R. J., Worthington, A. E., and Lucas, D. R., 1969. Ultra-long spaced electric log (ULSEL). Soc. Prof. Well Log Analysts Trans. 10th Ann. Logging Symp., H1-H22.

Salisbury, M. H., Donnelly, T. W., and Francheteau, J., 1980. Geophysical logging in Deep Sea Drilling Project Hole 417D. In Donnelly, T., Francheteau, J., Bryan, W., Robinson, P., Flower, M., Salisbury, M., et al., Init. Repts. DSDP, 51, 52, 53: Washington (U.S. Govt. Printing Office), 705-713.

Salisbury, M. H., Christensen, N. I., Becker, K., and Moos, D., 1985. The velocity structure of layer 2 at Deep Sea Drilling Project Site 504 from logging and laboratory experiments. In Anderson, R. N., Honnorez, J., Becker, K., et al., Init. Repts. DSDP, 83: Washington (U.S. Govt. Printing Office), 529-539.

Schlumberger, C., Schlumberger, M., and Leonardon, E. G., 1934a. Electrical coring: a method of determining bottomhole data by electrical measurements. Trans., AIME, 110:237-272. 1934b. A new contribution to subsurface studies by means of electrical measurements in drill holes. Trans., AIME, 110:273-288.

Sen, P. N., Scala, C., and Cohen, M. H., 1981. A self-similar model for sedimentary rocks with application to the dielectric constant of fused glass beads. Geophysics, 46:781-795.

Shipboard Scientific Party, 1979. Site 395: 23N, Mid-Atlantic Ridge. In Melson, W. G., Rabinowitz, P. D., et al., Init. Repts. DSDP, 45: Washington (U.S. Govt. Printing Office), 131-264.

1988. Site 395. In Bryan, W. B., Juteau, T., et al., Proc. $O D P$, Init. Repts., 109: College Station, TX (Ocean Drilling Program), 175-202.

Stephen, R. A., 1985. Seismic anisotropy in the upper oceanic crust. J. Geophys. Res., 90:11383-11396.

1988. Lateral heterogeneity in the upper oceanic crust at Deep Sea Drilling Project Site 504. J. Geophys. Res., 93:6571-6584.

Stephen, R. A., and Harding, A. J., 1983. Travel time analysis of borehole seismic data. J. Geophys. Res., 88:8289-8298.

Sundberg, K., 1932. Effect of impregnating waters on electrical conductivity of soils and rocks. Trans. AIME, 79:367-391.

Von Herzen, R. P., Francis, T. J. G., and Becker, K., 1983. In situ large-scale electrical resistivity of ocean crust, Hole 504B. In Cann, J. R., Langseth, M. G., Honnorez, J., Von Herzen, R. P., White, S. M., et al., Init. Repts. DSDP, 69: Washington (U.S. Govt. Printing Office), 237-244.

Waxman, M. H., and Smits, L. J. M., 1968. Electrical conductivities in oil-bearing shaly sands. Soc. Petrol. Eng. J., 8:107-122.

Worthington, P. F., 1975. Quantitative geophysical investigations of granular aquifers, Geophys. Surveys, 2:313-366.

Date of initial receipt: 20 June 1988

Date of acceptance: 24 April 1989

Ms 106/109B-145 